\title{
A Kárpát-medence orvoslása, gyógyszerészete és orvosképzése a kőkorszakban - a tatárlakai agyagtáblák üzenetének megfejtése
}

\author{
Györfi András dr. \\ Margittai Városi Kórház, Margitta, Bihar megye, Románia
}

\begin{abstract}
A Naprendszer első orvosi jellegű dokumentuma mintegy hétezer éves, és az Erdélyben található Tatárlaka község területén folytatott régészeti feltárások során került elő 1961-ben. A három agyagtáblán kódolt információcsomag megfejtése mostanáig nem járt sikerrel, mert az elemző́k csak a hieropiktogramokra koncentráltak. Márpedig a lelet sokkal komplexebb: egy fej nélküli női csontváz és 32 égetett agyagból és alabástromból készült objektum (amulettek, idolok), valamint egy, az Égeitengerből származó kagylóból készített karperec maradványai kerültek elő a rituális temetkezési helyről. Míg a három amulett épen maradt, a többi idolt és a karperecet valamiféle szertartás során darabokra törték, és úgy kerültek eltemetésre. Ezt figyelembe véve válhat világossá a hieropiktogramok üzenete: a lelet az első (ismert) kőkorszaki, baleseti sebészetre szakosodott orvosi-sámáni praxis kelléktárát tartalmazza. A gyógyítás kétkomponensû volt: a szakmai eljárásokat kódoló agyagtáblák épen maradtak, a túlvilági szellemekkel való kommunikálásra szolgáló idolok - amelyek a sámán személyes kelléktárához tartoztak - összetörve kerültek a kegyeleti helyre. A leleten található szimbólumok arra utalnak, hogy az írás előfutárának tekinthetô piktogramokat a Kárpát-medencében alkalmazták a világon először. Az agyagtáblák egyben bolygónk első tudományos dokumentumának is tekinthetők, mert az épen maradt táblák olyan sebkezelési eljárásokat kódolnak, amelyeket megfigyeléssel, hipotézisfelállítással, kísérletezéssel és az eredmények elemzése révén dolgoztak ki. A leletegyüttes állapota pedig arra utal, hogy ebben az erdélyi kőkorszaki közösségben az orvosi és gyógyszerészeti ismeretek oktatása, továbbadása is meg volt szervezve.
\end{abstract}

\section{Az orvoslás kezdetei - amit eddig tudtunk}

A gyógyítás tudománya valószínúleg egyidős az emberiséggel, és szoros kapcsolatban állott minden időkben a Természetről alkotott világképpel. Ennélfogva a kőkor- szakban nem beszélhetünk a mai értelemben vett orvoslásról: a történelem előtti időkben a betegségeket és a baleseteket többnyire az ártó és védő szellemek közötti erőegyensúly megbomlása következményének tekintették. Ezért ha bekövetkezett a baj, akkor a közösség úgy próbált segíteni a póruljárton, hogy ezt az egyensúlyt helyrebillentsék: a szellemekkel való kapcsolattartásra alkalmasnak ítélt tagjuknak/tagjaiknak kellett könyörgéssel, fenyegetőzéssel, síppal, dobbal, nádi hegedûvel beindítani a gyógyulási folyamatokat [1]. A jelenleg elfogadott álláspont szerint az első, empirikusnak nevezhető, gyógyító célzatú kísérleteket a gyógynövények alkalmazásával kapcsolatban az indiai szubkontinensen végeztek. Az Ájurvéda (szanszkritul az ájur életet, a véda pedig tudományt jelent) szájhagyomány útján terjedt már i. e. 3500 előtt - írásos formában csak az árják betelepedése után (i. e. 1500 körül) jelent meg a Védákban: a Rigvéda himnuszaiban az emberi szervek részletes anatómiai leírása található, az Atharvavédában pedig gyógyhatású szertartások és varázsigék mellett racionális és empirikus módon akalmazott drogokat is említenek. Megjegyzendő, hogy a területet az árják előtt is fejlett társadalom lakta: az Indus-völgyi civilizáció korából fennmaradt városokban közegészségügyi megfontolásokból tervezett ivóvíz- és szennyvízhálózatokra bukkantak. Harappában, Mohendzsodáróban és környékén i. e. 3300-tól kezdve mintegy két évezredig virágzott ez a társadalom - melynek írását a mai napig nem sikerült megfejteni [2].

Az első fennmaradt orvosi dokumentum sokak szerint a civilizáció bölcsőjének tekinthető Sumer Birodalomból származik [3]. Ur városának III. szakaszában - i. e. 2112-2004 - jött létre egy agyagtáblára rögzített terápiás kézikönyv, amely kezelési útmutatásokat sorol fel. Mivel diagnosztikai eljárások nem szerepelnek rajta, valószínúleg egy azú (a gyógyszerész előfutára) tulajdona lehetett, nem egy asipué (az orvosi hivatás előfutára). Az agyagtábla több ezer évig hevert Asszurbanipál palotájá- 
nak romjai alatt, mert az Újasszír Birodalom tudós uralkodója Ninivébe hozatott minden régi írásos agyagtáblát (többek között a Gilgames-eposzt megörökítőt is). Ám az ékírásos szöveg olvasható maradt, mert i. e. 612-ben, amikor a méd és újbabiloni csapatok feldúlták a várost, mindent felégettek - de ez az agyagtábláknak jót tett, konzerválta azokat az utókor számára [4].

Egyiptomi források ennél régebbi orvosi vonatkozású dokumentumokról is tudnak: Dzsószer fáraó fóépítészéről és foopapjáról, Imhotepről is maradtak fenn utalások, miszerint gyógyítással is foglalkozott volna [5]. Ez kétséges ugyan, az azonban majdnem bizonyos, hogy a kor legsikeresebb fogorvosi praxisát i. e. 2670 körül Hesziré (Hesy-Ra) vezette; a birodalom legjelesebb orvosa pedig Merit-Ptah volt ekkoriban: e cikk megjelenéséig őt tartották világunk első orvosnőjének. Írásos orvosi dokumentumok nem maradtak fenn ebből a harmadik dinasztiának nevezett korból, de az i. e. 1800 körül keletkezett Kahun nőgyógyászati papirusz (amely női bajokkal, fogamzással és fogamzásgátlással kapcsolatos dolgokat tárgyal), a ramesszeumi papirusz (szemészet, gyerek- és nőgyógyászat, mozgásszervi betegségek), illetve az Edwin Smith-papirusz (i. e. 1600 körül, 48-fajta traumatológiai eset diagnosztikáját, kezelését, prognózisát tárgyalja) mind régebbi keltezésú, mára már elveszett dokumentumok másolatainak vagy feldolgozásainak tekinthetők.

\section{Hol (és kik) ringatták az emberi civilizáció bölcsőjét?}

Archeológiai leletek sokasága tanúsítja, hogy öt-hétezer évvel ezelőtt a Pannon-medence a civilizált világ központjának számított. Amikor a Sumer Birodalom adóhatósága még nem találta fel a furfangos ékírást az adósok nyilvántartása érdekében, amikor az egyiptomi fáraók még nem kezdtek el összkomfortos piramisokat építtetni az Orion csillagkép övének vetületeként, és amikor Stonehenge leendő trilithonjainak helyét még csak elkezdték facölöpökkel kijelölni a szigetlakók (akik soha életükben nem hallottak keltákról, druidákról és egyéb fantazmagóriákról, amelyek szerint a druidák építették volna a Lebegő Kövek monumentumát) - vagyis mintegy 6000 éve - vidékünk a nagy kultúrák találkozásának színhelye volt. Tőlünk kevéssel keletre a Cucuteni-Tripolje-kultúra kezdett kialakulni: a Keleti-Kárpátok két oldalán a Dnyeszterig terülő hatalmas területen összefüggő népesség telepedett le. Békés, szorgalmas földmüvesek és állattartók voltak - és magas etikai mércéjük messze meghaladta a korabeli primitív mezopotámiai emberhordákban akkoriban dívó rabszolgaságot. Keleti szomszédaink települései rendezettek voltak, a vízelvezető árkok kialakítása szervezett társadalmi életre utalt akárcsak Harappában és Mohendzsodáróban. Társadalmuk valószínúleg nem elnyomáson alapult, és szomszédaikkal békességben éltek, mert a régészeti leletek között nem bukkantak fel fegyverek. Kultúrájukra a spirálvonalas díszítésű kerámia jellemző, valamint a fơként női testeket ábrázoló agyagszobrocskák - de egy 6000 évesnek ítélt, kerekeken guruló bika miniatúrje fölveti annak lehetőségét is, hogy a kerék feltalálása a $\mathrm{Cu}$ cuteni-kultúrához lenne köthető [6] - pedig a múlt században még ezt is a sumerek számlájára írták [7].

A Cucuteni-kultúrától délre, nagyjából a mai Dobrudzsa területén a Hamangia-kultúra virágzott - az i. e. VI. évezred közepétől. Kultúráját a mértani mintákkal díszített cserépedények jellemezték - de legjellemzőbb alkotása a mai Cernavoda város területén fellelt két szobor: a Gondolkodó és az Ülő nő, amelyek sokak szerint az egész kőkorszak legszebb múvei.

A kőkorszak végén a mai Dél-Magyarország, Erdély, Partium és a szerb Bánát területén a Körös-kultúra átadta helyét a Tordos-Vincsa-kultúrának. E két civilizáció közötti átmenet ideje (i. e. 7000-5000) régészeti szempontból tekintve meglepően rövid volt - aminek több, de egymással összefüggő oka is lehetett:

- egy távoli, magasan fejlett társadalom küldötteinek érkezése,

- őseink megismerték a Réz-hegység ásványkincsei felhasználásának technológiáját,

- elsóként alkalmazták az agyagtáblákra való adatrögzítést,

- elsóként alkalmazták azt a tudományos módszert, mellyel az első orvostudományi dokumentumot sikerült előállítaniuk.

Először is tisztáznunk kell a kultúra nevét. A bevett szokás szerint egy kultúrát az első régészeti feltárás helyének felhasználásával kell elnevezni. A Körös-kultúrát felváltó új társadalom vidékünkön az i. e. VII. évezred táján kezdett elterjedni - és az első leleteket Torma Zsófia, az első magyar régésznő (a későbbiekben a Kolozsvári Egyetem díszdoktora) tárta fel 1875-tel kezdődően, és kezdte publikálni 1879 májusától [8]. Munkásságát sokan nagyfokú hitetlenséggel kezelték - annak ellenére, hogy több ezer cseréptöredéken a sumer ékírás jeleivel nagymértékben egyező hieropiktogramokat szedett rendszerbe [9]. A XIX. és a XX. század eleji véleményformálók nagy része azonban képtelenségnek tartotta a régésznő által sugallt sumer-erdélyi kapcsolatot. Ez is hozzájárulhatott a kőkorszaki régészetre szakosodott tudóstársadalom vezéralakjának kikiáltott Colin Renfrew nevü brit úriembernek ahhoz a téves döntéséhez, hogy az akkoriban feltárt kultúrát a Vincsa melletti régészeti lelőhelyről nevezze el. Vincsa a Duna bal partján fekszik, Belgrádtól 14 km-re délre. Itt az ásatásokat csupán 1908-ban kezdte el Miloje Vasics - évtizedekkel Torma Zsófia kutatásainak megkezdése után.

\section{A tatárlakai agyagtáblák üzenetének megfejtésére tett eddigi kísérletek}

A Körös-kultúrát felváltó Tordos-Vincsa-kultúra repülőrajtot vett a környezetében élő békés és szorgalmas népességekhez képest: sem a Cucuteni-, sem a Hamangia- 
kultúrához tartozó leleteken nem találhatók írásjelek, logogramok (szavakat jelölő egyszerú ábrák), piktogramok (a leírt tárgyhoz hasonlatos ábrácskák) vagy ideogramok (fogalmakat jelölő ábrácskák). A kőkorszak végéig jellemző teljes kommunikációs csenddel szemben a Torma Zsófia által Tordos környékén feltárt mintegy 11000 lelettárgy nagy részén pikto- és ideogramok láthatók: valaminek a hatására az emberek elkezdtek maradandó jelek révén kommunikálni. Az akkori civilizáció jelenleg ismert legkomplexebb alkotását pedig a Tordostól mintegy $18 \mathrm{~km}$-re nyugatra, szintén a Maros folyó árterületén fekvő Alsó-Tatárlaka külterületén találták meg. Az itteni lelet létrejöttének idejét radiokarbonos meghatározással körülbelül i. e. 5300-ra lehet datálni [10]. Az egyiptomi hieroglifák a Naqada-kultúra idején kezdtek megjelenni i. e. 3200 körül. Ezt talán valamivel megelőzte a sumer ékírás kialakulása, amely Uruk városállam területén jelent meg az i. e. IV. évezred vége felé, és 3100 körül a város Dzsemdet Naszrnak nevezett periódusában kezdett elterjedni. Ezek a jelek tehát arra utalnak, hogy mintegy hétezer éve vidékünkön olyan események zajlottak, amelyek az első kommunikációs forradalom - az írás megjelenéséhez vezetett. Majdnem kétezer év múlva a tordosi jelkészlet felbukkant a mezopotámiai, majd az egyiptomi íráskezdemények kialakulása során.

Ha arra kezdenénk magyarázatot keresni, hogy a tatárlakai korong üzenetének megfejtése miért nem sikerült mostanáig, leginkább a kutatók látókörének beszűkülésében keresném az okokat. Az eddigi megfejtési javaslatok nagy része csak magukra a korongokra vonatkozott, sőt sokan csak a rájuk vésett szimbólumokkal foglalkoztak. Márpedig ha eltekintünk attól a szellemi környezettől, amelyben ezek a múalkotások létrejöttek, ha nem vesszük figyelembe, hogy a leletanyag pontosan miben állt, és milyen állapotban találtak rá, akkor szinte semmi esélyünk nem marad az üzenet megfejtésére.

Márpedig 7000 éve ez a vidék nem csak abban különbözött mai világunktól, hogy nem volt iskola vagy ipar vagy tömegközlekedés. A fö különbség abban állott, hogy az emberek addig nem ismerték az írást: ezért nevezik történelem előttinek azokat az időket. De nagyot tévednénk, ha azt feltételeznénk, hogy az írástudatlanság egyúttal gyengeelméjűséget vagy kommunikációra való képtelenséget is jelentett. Mert eleink nagyon határozott elképzeléseket alakítottak ki a dolgok és a jelenségek okainak magyarázatára, és ezeket a nézeteket igen hatékonyan tudták térben és időben terjeszteni: sokunknak a mai napig nehezére esik eltaposni egy utunkba kerülő bogarat vagy leszakítani egy faágról a levelét. Egy kőkorszakban kialakult nézet szerint ugyanis lelke van a bogárnak, a fának és minden élőlénynek - és ezek a lelkek kapcsolatban állanak az Anyatermészettel. Aki nagyon nem szereti, ha az ember oktalanul bántja ezeket a lelkeket. Vihart gerjeszthet, vagy aszályt, árvizet és klímaváltozást. Ha meg akarjuk tehát érteni, hogy mit üzennek eleink, meg kell próbálnunk először megérteni, miként gondolkodhattak. Mert erre igenis találhatunk utalásokat a régészeti leletekben. A Közel-Keleten kialakulandó nagyhatalmakkal szemben vidékünkön nem dívott sem a rabszolgaság, sem a háborúskodás. Ám a fegyverek hiánya távolról sem jelenti azt, hogy őseink lagymatagok lettek volna. Ne feledjük, hogy Kömíves Kelemen balladájának gyökerei innen erednek: az emberáldozat, sőt a gyermekáldozat általánosan ismert és gyakorolt eljárás volt akkoriban - akár egy nagyobb horderejű döntés meghozatalakor vagy vállalkozás beindításakor -, de súlyosabb természeti csapásoknak is úgy próbáltak véget vetni, hogy ártatlan embereket küldtek a túlvilágra könyörgő követnek. Szintén régészeti leletek bizonyítják, hogy az antropofágia is dívott akkoriban tájainkon: a kannibalizmus egy rituális formájáról van szó, amelynek során az elhunyt fejét elválasztották a törzstől, megfőzték, majd a nagycsalád közösen elfogyasztotta az agyvelőt, hogy rokonuk lelke tovább éljen az ittmaradottakban. A régészeti leletek nagy számban tártak fel a túlvilági erőkkel való kapcsolattartásra szánt tárgyakat: oltárokat, áldozati kelyheket, jó vagy ártó szellemeket megtestesítő szobrocskákat stb.

Márpedig a tatárlakai lelet sokkal többet jelentett, mint a három agyagtáblácskára vésett üzenet: a lelet egy rituális temetkezési helyről származik, melyet Nicolae Vlassa kolozsvári régész 1961-ben tárt fel. A hamuval kevert földből ugyanis emberi csontok mellett 32 egyéb tárgy került elö:

- az említett 3 agyagtáblácska,

- 26 égetett agyagszobrocska töredékei, melyeknek hengeres testük és háromszögü arcuk volt,

- 2 alabástromidol,

- 1 darab (valószínúleg az Égei-tenger vidékéról származó) Spondylus kagylóból készült karperec.

Ami a csontokat illeti, az alaposabb vizsgálatok arra utalnak, hogy egy 50-55 éves nőé voltak, akit jóval a halála után helyeztek a másodlagos temetkezési helyre miután a hús lefoszlott a tetemról. A koponyacsontok hiányoztak, de az antropometriai adatok szerint a személy körülbelül $147 \mathrm{~cm}$ magas lehetett, és a jobb lábára erósen sántított, ami gerincferdüléshez vezetett.

Lássuk hát, milyen megfejtési javaslatok jöhetnek számításba a három artefaktumon látható ábrázolások tekintetében.

1. Nicolae Vlassa, a feltáró régész mágikus és rituális jelentést tulajdonított az agyagtáblákon látható piktogramoknak, és felismerte a jelek hasonlóságát a mezopotámiai ékírás előfutárát jelentő szimbólumokkal ( 1 . ábra).

2. Gheorghe Lazarovici, Vlassa tanítványa az olasz Marco Merlinivel szövetkezett, hogy fényt derítsen az általuk Tatárlakai Nagyasszonynak nevezett (Milady Tartaria) kőkori főpap vagy sámán tulajdonát jelképező tárgyak jelentőségére [10]. Az 1-es táblácskán (a lyuk nélkülin) leírják a trónon ülő pásztor motívumát, az élet fáját és a kecskenyájat. A 2-esnek nevezett korongon leírják a keresztet, amely négy negyedre osztja a képet: a 


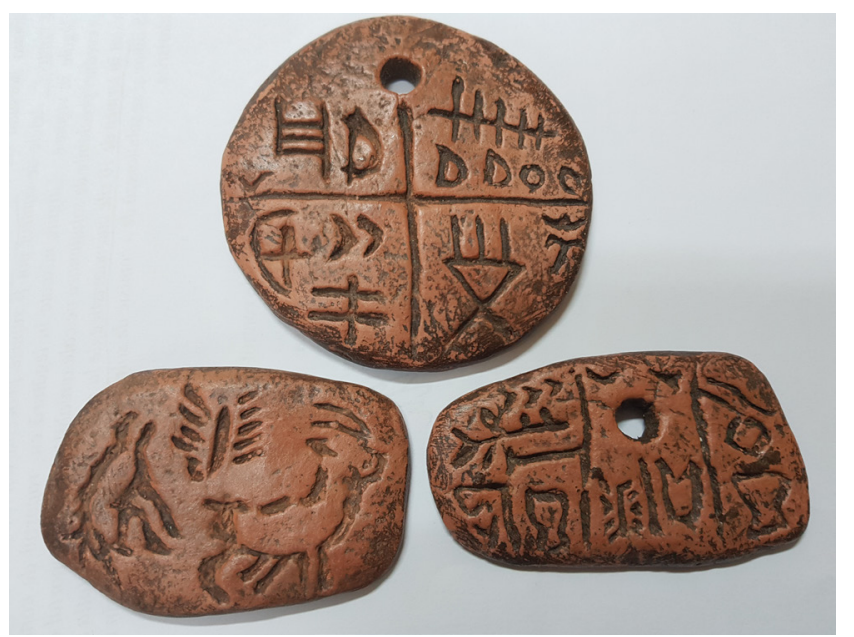

1. ábra

Tatárlakai agyagtáblák. A reprodukciókat Silaghi Gabriel Stelian margittai képzőmúvész készítette

bal felsóben egy trónust látnak, és a D betû alakú Holdat. A jobb felső negyedben a holdfázishoz igazodó női menstruációs naptárat látnak, amelyen a felső sor közepében lévő Hold-szimbólumnak az alsó sorban található Hold-szimbólumok egyikével való érintkezése arra utalna, hogy a nők a ciklusuk 13-14. napján termékenyíthetők meg a legjobb eséllyel. (Ez mondjuk igaz, de az nem világos, miból gondolja Lazarovici, hogy a harmadik vonal, amely érinti az alatta levő sorban található D-k egyikét, a női ciklus 13. napját jelöli. A D-k sorozata szerintem nem azonosítható a Hold ciklusaival, vagyis a növő, teli-, illetve fogyó Holddal). A bal alsó negyedben látható, esernyő alakú jelet íjként azonosítják, és látnak még két nyílhegyet. Nem zavarja az értelmezőt, hogy a nyílvessző nincs beakasztva a húrra, és hogy a nyílhegyek az ellenkező irányba mutatnak. Mint mondottam, a kőkorszaki embereknek nem voltak különösebb kognitív problémáik: nem hiszem, hogy akik nap mint nap használták a nyilat, ily módon ábrázolták volna azt. A lefektetett $\mathrm{H}$ betûnek látszó szimbólum pedig szerintük a fényeket jelöli (?). A jobb alsó negyed pedig két elemet tartalmaz: az égő (füstölő) áldozatok oltárát és egy mennyei oltárat, amelyet lehet felemelt karú emberi alaknak is értelmezni.

A kisebb átfúrt korongon Lazaroviciék a Nap szimbólumát látják a lyukban, egy ökörfejet, az élet fáját, egy serleget és egyéb növényeket, amelyek az Anyatermészet egyes elemeit jelképezik. Felhasználási módjukat tekintve elmondható, hogy az átfúratlan táblácska pompásan illeszkedik az ember bal kezébe. Lazaroviciék azt is felvetették, hogy ha a két átfúrt táblát felfüzzük egy madzagra, akkor a kisebbik tábla ráillik a korongra, eltakarván ekként a két felső mezőt - tehát valamiféle beavatási szertartásban is használhatók lehettek. A három korong szerintük rituális célokat szolgált, melyeket a közösség egy beavatott vezetője használt vallásos ceremóniák során.

3. A sumer írásjeleket ismerő nyelvészek megpróbálták „elolvasni” a táblákra vésett jeleket. A téglalap alakú át- fúrt tábla olvasata Harmatta János nyelvészprofesszor szerint [11]: Ru Be Iá Ás U Se U Ansu Uru Unu, ami magyarra fordítva így hangzik: Fogadalmi ajándékul adott az Úrnak 5 kenő edényt, 10 kur árpát, 10 lovat Unu városa. A korong olvasata pedig: Zid Gis U / Igi Nis Ensi / Ziz Gis Gis Min / Ara Utu, ami annyit tenne, mint Liszt $60+10$ kur Palil istennek, 20 kur a fópapkirálynak. Búza $60+60+2$ kur Usmu istennek, Samas istennek. Hasonló értelmezést vélt látni Adam Falkenstein német asszirológus és Makkay János, az őstörténelem professzora is. Véleményük szerint a korongok fogadalmi ajándékokként értelmezendők, és azért volt kettő átfúrva, hogy a szent helyen felakaszthassák a falra vagy valami jól látható helyre. A mezopotámiai Pantheonban azonban Palil nevü isten nem szerepel, Usmu nem isten volt, hanem az egyik sumer föisten, Enki „személyi titkára”, küldönce - akinek különös ismertetőjegye a kétarcúság volt. Végül pedig Samas, a Napisten neve a sumer időkben Utu volt - a Samas forma csak a későbbi, akkád és babiloni szövegekben fordul elő. Ezért valószínúleg ez a megfejtés sem helyes: nem szerepelhet egy hétezer éves korongon Usmu neve mellett a Napistennek egy olyan megnevezése, amelyet csak néhány évezred múlva vesznek majd használatba.

4. A National Security Agency-nél alkalmazott, a matematikai kriptográfia elemeit is ismerő nyelvész, Keith Massey matematikai rejtvényként „oldotta meg” a tatárlakai korong feliratát [12]. Szerinte a jobb felső negyed olvasata 60: egy hosszú vízszintes vonalat 6 rövid vonal metsz - és ugyanazt jelenti alatta a két Hold- (a holdciklus 29,53 napos) és két Nap-szimbólum is: $60=29+29$ $+1+1$. Az alatta levő negyedből Massey csak az üstból felszálló három füstcsíkot veszi számításba - tehát a 3-as értéket tulajdonítja ennek a negyednek. A bal alsó negyed esetében az áthúzott $\mathrm{D}$ betüt 14-nek tekinti (pedig már az is túlzott nagylelküségre vall, hogy korábban 29re kerekítette a 29,53 napos holdciklust - most tovább rövidíti, csak hogy kijöjjön a számítása). A nyílhegyet a 3-as szám megfelelőjének tekinti (merthogy három pont összekötésével alakul ki az ábra), a kétszer áthúzott szakasz pedig az előbbi okfejtés alapján 20. Tehát ennek a negyednek a megfejtése $14+3+3=20$. És az összefüggés: $3 \times 20=60$ ! A bal felső negyed megfejtése sántít: a D jel 29-nek felel meg, de hogy a három vízszintes és a két függóleges vonal miként adná meg ezt a számot, azzal adós marad Massey. Pedig érvelésének lényege az lenne, hogy a korongot akkor használták, amikor az egyik számolási rendszerról áttértek a másikra: a 29 napos holdnaptárról a tízes számrendszerre. Az érvelés ott sántít, hogy a bal felső negyedben a számok nem jönnek ki, a jobb alsóban pedig egy másik szimbólum jelöli a 3-as számot, mint a mellette levő mezőben.

5. Érdekes elgondolással állott elő Záhonyi András: a korongon a Szekeres, az Ikrek, a Hydra, a Mérleg és a Farkas, a Kígyó a Déli Koronával, a Skorpió, a Nyilas és a Sas csillagképek láthatók szerinte [13]. A csillagképek valóban egymás szomszédságában vannak - de nem ép- 
pen úgy, ahogy a szerző leírja. Másfelől a korongon látható ábrák és csillagképek megfeleltetése is kétséges. További probléma, hogy nagyon halvány csillagokból álló alakzatok szerepelnek Záhonyi szerint a korongon (például a Mérleg legragyogóbb csillaga, a Beta Libri magnitúdója csupán 2,60), ellenben a Nagy Medve, a Göncölszekér, a Kis Medve vagy a Szűz (legfényesebb csillaga a Spica 0,95-ös magnitúdójú) és az égbolt legfényesebb csillagát (a Szíriuszt, -1,45-ös fényrend) tartalmazó Nagy Kutya csillagkép nincs megemlítve a Záhonyi által csillagórának nevezett tatárlakai korongon.

Vannak egyéb megfejtési javaslatok is: van, aki a székely rovásírás betúkészletének előfutárát látja a korongon, az oroszok ősszlávok üzenetét veszik, a szerbek etruszk ábécével szerb nyelven olvassák a jeleket [14], stb. - lássuk hát, mi az üzenete az emberi civilizáció első tudományos igényú dokumentumának, mely határt szab a történelem kezdete és a történelem előtti idők között.

\section{A tatárlakai agyagtáblák: az első orvosi és gyógyszerészeti kompendium}

Ha figyelembe vesszük, hogy a rituális temetkezési gödörben a három épen maradt agyagtábla mellett egy, a közösség által különlegesen tisztelt idős nő csontjai is előkerültek, valamint olyan szellemek megidézésére szolgáló szobrocskák, amelyeket valamilyen szertartás során kettétörtek, világossá válhat a táblácskákra vésett jelek értelme. A jelek szerint a súlyosan beteg, idős nő a törzs szellemi vezetője és gyógyítója volt, aki az idolok felhasználásával hitette el a közösséggel, hogy kapcsolatba tud lépni a betegségeket és baleseteket okozó szellemvilággal. Ám tudománya kiterjedt olyan eljárásokra és beavatkozásokra is, amelyek megfigyelésen, kísérletezésen és módszeres elemzésen alapultak. Tehát a szellemekkel való kapcsolatot a sámán személyéhez köthetőnek tekintették - ezért az idolokat eltörték és úgy helyezték a sírba. A gyógyításhoz szükséges empirikus és nagyon is evilági tudást rögzítő agyagtáblák azonban a kiválasztottak oktatására szolgáltak, ezért lemásolhatták a beavatottak számára - és az eredeti darabokat eltemették a sámánjukkal.

Az agyagtáblákat illetően, a korong két felső mezeje két baleseti sebészeti sürgősség ellátásának az alapelveit kódolja. A bal oldali mező kis $\mathrm{V}$ alakú szimbóluma az elmozdulással járó hosszú csöves csont törését jelöli. A mellette levő piktogrammal (amelyet Harmatta profeszszor a Labat epigráfiai kézikönyve [15] 536-os szimbólumával azonosít: ZID, vagyis liszt) a rögzítősín alkalmazását írja elő a korong. Ugyanis szerintem itt nem a ZID sumer olvasatot kell rendelni az 536-os jelhez, hanem a TÚG olvasatot, amely magyarul szúk nadrágot jelent. Akinek volt már gipszben a lába, megértheti, miért. A rögzítősín melletti, D betúhöz hasonló jel a zúzott test- részre alkalmazott, a nyírfa taplógombájából (Piptoporus betulinus, egy D betúhöz hasonlatos alakú gomba) készített pakolást jelöli. A növényből kinyerhető triterpenoidoknak és egyéb hatóanyagoknak antimikrobiális és gyulladáscsökkentő hatásuk van - ezért is alkalmazták ősidők óta a népi gyógyászatban [16]. Tudta ezt Ötzi is, a jégkorszaki vándor: az osztrák Alpokban talált múmia bugyellárisában néhány adagnyit találtak a régészek ebből a gombából. A jobb oldali mező pedig a sebvarrás technikájára utal: a sebet hat öltéssel varrta össze a sámán, majd taplógomba-pakolást (piktogramja a $\mathrm{D}$ betúk), mák és belladonna (piktogramjuk a nyílt és a zárt ovoid jel) főzetéből előállított fájdalomcsillapító és bódító hatású italt javasolt a sebesültnek. A korong alsó mezői azokat a folyamatokat jelölik, amelyekkel a gyógyhatású termékeket előállítják és alkalmazzák: a bal oldali mezőben egy mozsár szimbóluma látható, melyben a gyógynövényeket megtörik, a repülö méhek (a háromszögek) a mézet jelölik, melyet külsőleg és belsőleg egyaránt használtak. A kettős kereszt pedig a mindkét esetben alkalmazott kötözés ideogramja. A jobb alsó negyedben a fózet elóállításának folyamatát jelöli a talpas edényből fölszálló három gőzcsík, a fohászra emelt kezú alak pedig arra a ceremóniára utal, amelynek része volt a szellemek megidézése és maga a kezelés is.

A téglalap alakú lyukas táblácska egy teljes kőkorszaki Pharmacopoeia: a sámán által használt gyógyhatású készítmények listája. A dokumentum két részből áll, amelyek fejezetekre vannak osztva. A bal oldali részben 4 fejezet van: az óramutató járásával megegyező irányban haladva, az első fejezetben (felül) a vízszintes növényi szár levelekkel a rozmaring (Rosmarinus officinalis) jele, amelynek antimikrobiális hatását modern kutatások bizonyították [17]. Az ugyanebben a fejezetben látható háromszögek pedig a repülő méhekre utalnak, illetve az általuk termelt mézet jelölik.

A második fejezetben a függőleges növényi szár a közönséges cickafark (Achillea millefolium) [18]. A görög mitológia szerint Kheirón volt a legbölcsebb kentaur, aki orvostudományra oktatta Aszklépioszt, és Akhilleusznak azt tanácsolta, hogy a trójai háborúba cickafarkot vigyen magával a katonák harctéri sebeinek kezelésére - innen a növény hivatalos latin neve. A harmadik fejezet a söré, melyet egy kupában tároltak, és belső használat mellett sebek mosására és fertőtlenítésére is használták. A negyedik fejezetben a kakukkfü (Thymus vulgaris) következik, melynek hatóanyaga, a timol antimikrobiális fertőtlenítőszerként is használatos.

A jobb oldali részben csak két fejezet van: az ökörfej és a főzetbe helyezett valamelyik gyógynövény szimbóluma.

A harmadik táblácska, amely nincs kilyukasztva, két gyógynövényt mutat be: a fekete nadálytő gyökerét (Symphytum officinale, radix), mely tapaszként sebek és 
égések kezelésére alkalmas, valamint ízületi bántalmakra, és az orvosi zsályát (Salvia officinalis), amely antimikrobiális, gyulladáscsökkentő és fájdalomcsillapító hatású összetevőket tartalmaz [19]. A táblácskán látható még egy kecske, amely a honoráriummal lehetett kapcsolatos.

\section{Összefoglalás}

A tatárlakai lelet fentebbi értelmezése azt bizonyítja, hogy mintegy hétezer éve a mai Erdély és Dél-Magyarország területén egy komplex ismeretrendszert kezelni tudó társadalom élt, amely a világon először alkalmazta az írás előfutárának tekinthető piktogramokat és ideogramokat - nemcsak rituális, hanem mnemotechnikai és oktatási célokra is. A súlyos balesetek következményeként előforduló sérülések ellátása, valamint a gyógyhatású készítmények listája arra utal, hogy a táblácskák készítôi ismerték és alkalmazták a tudományos módszert a törések és nyílt sebek esetében:

1. Megfigyelés (a csonttörések helyreillesztett törvégek esetében jobban gyógyulnak / a sebszélek közelsége esetén jobb gyógyulás)

2. Hipotézis felállítása (a sámán beavatkozásával a törvégek egyenesbe hozhatók / a sebszélek varrattal közelíthetők)

3. Előrejelzés (feltételezték, hogy ezek az eljárások jobb gyógyuláshoz vezetnek)

4. Kísérlet (ez a beavatkozás elég fájdalmas lehetett az áldozat számára)

5. Az eredmények elemzése

6. Hipotéziskorrekció (tapaszok, fájdalomcsillapítók, antimikrobiális szerek használata stb.) és így tovább.

A tordosi és a tatárlakai kultúra leletei a következőket bizonyítják:

1. Az írás előfutárának tekinthető pikto- és ideogramokat legelőször a Kárpát-medencében kezdték alkalmazni az információ rögzítésére és továbbítására i. e. 5400 körül - több, mint ezer évvel a sumer és az egyiptomi íráskezdemények megjelenése előtt.

2. A leletegyüttes egy komplex orvosi praxis kelléktárát tartalmazza.

3. Az agyagtáblák tulajdonosa súlyos, a törvégek elmozdulásával járó törések és nyílt sebeket okozó balesetek ellátásának menetét, az alkalmazott gyógyhatású készítmények listáját jegyezte fel.

4. A tudományos módszer alkalmazásának elemei ismerhetők fel a tatárlakai lelet pikto- és ideogramjaiban.

5. Az agyagtáblák egy beavatásszerú oktatási procedúra során a sebkezelési ismeretek továbbítására is alkalmasak voltak - tehát a kőkorszakban a tatárlakai közösség az első (általunk ismert) orvosi jellegú oktatási központ lehetett.

\section{Irodalom}

[1] Balázs P. Healthcare for money and by the calling to the profession. [Orvoslás pénzért és hivatástudatból. Tankönyv.] Melánia Kiadó, Budapest, 2002. [Hungarian]

[2] Selin H. (ed.) Encyclopaedia of the history of science, technology and medicine in non-Western cultures. Springer, Berlin, 1997.

[3] Scurlock J, Andersen RB. Diagnoses in Assyrian and Babylonian medicine. Ancient sources, translations, and modern medical analyses. University of Illinois Press, Champaign, IL, 2005.

[4] Kramer SN. History begins at Sumer. Thirty-nine firsts in recorded history. University of Pennsylvania Press, Philadelphia, PA, 1981.

[5] Benke J. The history of medicine. [Az orvostudomány története.] Medicina Könyvkiadó, Budapest, 2009. [Hungarian]

[6] Parpola A. Proto-Indo-European speakers of the Late Tripolye culture as the inventors of wheeled vehicles: linguistic and archaeological considerations. Available from: http://www.pies. ucla.edu/WeCIEC/parpola_a_2007f.pdf

[7] Zamarovský, V. In the beginning was Sumer. [Kezdetben volt Sumér.] Mladé Letá, Bratislava, 1966. [Hungarian]

[8] Torma Zs. Neolithic settlements in Hunyad county. [Neolith kőkorszakbeli telepek Hunyadmegyében.] Erdélyi Múzem 1879; 6: 5., 6., 7. szám. [Hungarian]

[9] Roska M. The collection of Zsófia von Torma in the Numismatic and Archaeologic Museum of Transsylvania. [A Torma Zsófia gyújtemény az Erdélyi Nemzeti Múzeum Érem- és Régiségtárában.] Gróf Teleki Pál Tudományos Intézet, Kolozsvár, 1941. [Hungarian]

[10] Lazarovici G, Lazarovici CM, Merlini M. Tartaria and the sacred tablets. Editura Mega, Cluj-Napoca, 2011.

[11] Harmatta J. Neolithic writing in Central Europe? [Neolitkori írásbeliség Közép-Európában?] Antik Tanulmányok 1966; 13: 235-236. [Hungarian]

[12] Massey K. The Tartaria tablets: a mathemathical interpretation. Available from: http://viyoutube.com/.../the $\% 20 \operatorname{tartaria} \% 20$ tablets:\%20a\%20math...

[13] Záhonyi A. The stellar watch of Tatárlaka. [A tatárlakai csillagóra.] Fríg Kiadó, Pilisszentiván, 2011. [Hungarian]

[14] Pešić R. The Vincha script: the first human alphabet. Kindle Edition, Pešić i sinovi, 2017.

[15] Labat R. Handbook of Akkadian epigraphy. [Manuel D'Épigraphie Akkadienne.] Librairie Orientaliste Paul Geuthner, Paris, 1948. [French]

[16] Pleszczyńska M, Lemieszek MK, Siwulski M, et al. Fomitopsis betulina (formerly Piptoporus betulinus): the Iceman's polypore fungus with modern biotechnological potential. World J Microbiol Biotechnol. 2017; 33: 83.

[17] Sienkiewicz M, Łysakowska M, Pastuszka M, et al. The potential use of basil and rosemary essential oils as effective antibacterial agents. Molecules 2013; 18: 9334-9351.

[18] Ali SI, Gopalakrishnan B, Venkatesalu V. Pharmacognosy, phytochemistry and pharmacological properties of Achillea millefoli$u m$ L. A Review. Phytother Res. 2017; 31: 1140-1161.

[19] Ghorbani A, Esmaeilizadeh M. Pharmacological properties of Salvia officinalis and its components. J Tradit Complement Med. 2017; 7: 433-440.

(Györfi András dr., e-mail: drgyorfiandras@gmail.com) 